\title{
Cost-Benefit Implications in the Emerging Electronic Banking Space in Nigerian Financial Sector
}

\author{
Hyginus I. Ihenetu \\ Department of Banking and Finance \\ Captain Elechi Amadi Polytechnic Rumuola, \\ Portharcourt \\ Augustine A. Anaele \\ Department of Economics \\ Ignatius Ajuru University of Education Rumuolumeni, \\ Portharcourt
}

Received: May 5, 2021

Accepted: May 22, 2021

Published: May 26, 2021

doi:10.5296/ijrd.v8i1.18680

URL: http://dx.doi.org/10.5296/ijrd.v8i1.18680

\begin{abstract}
The paper evaluated the cost-benefit implications in the emerging electronic banking space in Nigerian financial sector. Data were collected from CBN statistical bulletin and NDIC annual report. Twenty one (21) banks operating in Nigeria constitutes the population of the study and sample size of twelve (14) years was selected through purposive sample method. Auto-Regressive Distributive Lag (ARDL) was used to analyze the data after stationarizing it through Augumented Dicky Fuller (ADF) unit root test. The findings show that ATM, POS and MB have no significant effect while WIT has negative significant on banks' profit. The findings further reveal that the combination of these variables has positive and significant effect on banks' profit. We therefore recommend that banks should fully utilize the benefits provided through electronic banking by ensuring that more ATM terminals are provided in order to reduce crowd. Professionals that can constantly put the machine in order should be emlpoyed and there should be constant money in the machine to enable the banks make more profits and serve the people better at all times. POS should be made available to the users and at a reduced cost without hidden charges to enable people of different categories have access to them. This will help to generate revenue to the banks and reduce their cost of transaction etc.
\end{abstract}

Key words: Automated Tellers Machine, Point of Sale, Mobile Banking, Web (Internet) Transaction, Electronic Banking, Information Communication and Technology etc. 


\section{Introduction}

Nigeria financial sector, especially banks, has migrated from crude traditional method of paper works to highly sophisticated electronic banking in this modern time. Shehu, Aliyu \& Musa (2013) citing from Daniel (1999) describes electronic banking as the provision of banking services to customer through internet. According to them, electronic banking is defined to include the provision of retail and small value banking products and services through electronic channels as well as a large value electronic payment and other wholesale banking services delivered electronically. Electronic banking helps to give customers access to their bank account via a website and to enable them enact certain transactions on their account given compliance with stringent security checks (Essenger 1999). It is very easy to operate, enhance conveniences of the customers, very flexible and less time consuming.

The benefits associated with electronic banking in Nigeria are: the emergence of knowledge driven banking industry, global interconnectivity of the Nigerian banking industry with other economies, a sign post for growth and economic development, availability of diverse jobs, optimization of money value of time, widening of banking space by bringing in more persons both far and near into the banking space, increase in the volume of banking transaction due to increase in the number of clients and also increasing volume of revenues and profits.

The electronic banking available today in Nigeria's banking industries are Automated Teller Machine (ATM), Electronic Fund Transfer (EFT), Point of Sale (POS), Credit Card System (CCS), Debit Card System (DCS), Web (Internet) Transactions (WIT), Personal Computer Banking (PCB) etc.

Electronic banking is the product of information, communication and technology (ICT) which have taken over the world today. According to Dabwor, Ezie \& Anyatonwu (2017), ICT is the automation of processes, controls and information production using telecommunications, software and other gadgets that ensure smooth and efficient running of activities. Nigerian National Policy for Information Technology (2001) defined ICT as the computer ancillary equipment software and firmware (hardware) and similar procedures, services (including support services) and related resources, any equipment or interconnected system of equipment that is used in the automatic acquisition, storage, manipulation, management, movement, transmission or reception of data or information.

Regrettably, the cost involved in electronic banking in Nigeria to both banks and customers may outweigh the benefits if not properly managed. The cost are: increase in cybercrime both in-house fraud and external attackers of system apps and customers' account, loss of billions of revenues to technology induced and perpetrated frauds, shift of focus from real investments that will enhance quality of living to cyber security surveillance, cost of installation of the system, cost of maintenance, cost of personnel training, cost of powering, incessant system breakdown that leads to lack of customers confidence on the banks, breaking of secret code and hacking of customers secret pin number leading to huge stealing of customers money, inconsistency of services on the on-line connectivity, poor network, lack of privacy and confidentiality, unauthorized access and intrusion to financial institutions system and transaction, inaccurate data processing (sometimes by the system) etc. 


\section{Macrothink

Researches conducted on electronic banking in Nigeria only concentrated on the benefits derivable on the use of e-banking without considering the cost implications, this gap therefore becomes the central problem of the study.

The general objective of the study is to determine the cost-benefits implications of electronic banking in the Nigeria's financial sector. The specific objectives are:

i. To determine the effect of value of transaction of automated tellers machine (ATM) on banks' profit.

ii. To determine the effect of value of transaction of point of sale (POS) on banks' profit.

iii. To determine the effect of value of transaction of mobile banking (MB) on banks' profit.

iv. To determine the effect of value of transaction of web (internet) transaction (WIT) on banks' profit.

The following null hypotheses are stated:

$\mathrm{H}_{1}$ - The value of transactions of ATM do not have significant effect on banks' profit.

$\mathrm{H}_{2}$ - The value of transactions of POS do not have significant effect on banks' profit.

$\mathrm{H}_{3}$ - The value of transactions of MB do not have significant effect on banks' profit.

$\mathrm{H}_{4}$ - The value of transactions of WIT do not have significant effect on banks' profit.

\section{Literature Review}

\section{a) Conceptual framework}

Ojokuku and Sajuyigbe (2012) describe the following concepts:

i. Point of Sale terminals: POS terminals handle cheque verifications, credit authorization, cash deposit and withdrawal, and cash payment. This enhances electronic fund transfer at the point of sale (EFTPOS). EFTPOS enables a customer's account to be debited immediately with the cost of purchase in an outlet such as a supermarket or petrol station. It consists of the accumulation of electronic payment messages by the retailer, which are subsequently passed on to appropriate institutions for processing. The purchase price is debited on the buyer's account and credited on the seller's account.

ii. The Card System: The card system is a unique electronic payment type. The smart cards are plastic devices with embedded integrated circuit being used for settlement of financial obligations. The power of cards lies in their sophistication and acceptability to store and manipulate data, and handle multiple applications on one card securely. Depending on the sophistication, it can be used as a Credit Card, Debit Card and ATM (Automated Teller Machine) card.

iii. A credit card: This is a payment card issued to users as a system of payment. It allows the card holder to pay for goods and services based on the holder's promise to pay for them. The issuer of the card creates a revolving account and grants a line of credit to the consumer 
(or the user) from which the user can borrow money for payment to a merchant or as a cash advance to the user.

iv. A debit card: This is also known as a bank card or check card is a plastic payment card that provides the card holder electronic access to his or her bank account(s) at a financial institution. Some cards have a stored value with which a payment is made, while most relay a message to the card holder's bank to withdraw funds from a payee's designated bank account. Online debit cards require electronic authorization of every transaction and the debits are reflected in the user's account immediately. The transaction may be additionally secured with the personal identification number (PIN) authentication system; some online cards require such authentication for every transaction, essentially becoming enhanced automatic teller machine (ATM) cards.

v.Automated Teller Machine (ATM): An ATM device allows a bank customer to withdraw cash from his account via a cash dispenser (Machine), and the account is debited immediately. A fundamental advantage is that it needs not to be located within the banking premises. It is usually in stores, shopping malls, fuel stations etc. It saves customers time in service delivery as alternative to queuing in bank halls, customers can invest such time saved into other productive activities. ATMs are a cost-efficient way of yielding higher productivity as they achieve higher productivity per period of time than human tellers.

vi. Mobile Banking: Mobile Banking refers to provision and availment of banking- and financial services with the help of mobile telecommunication devices. The scope of offered services may include facilities to conduct bank and stock market transactions, to administer accounts and to access customized information.

vii. Web (Internet) Transaction: Web (internet) transaction allows checking web-based resources for performance and availability, adding capability to emulate web application user real-life behavior. You can transact a business by creating web transaction monitor, you load a start URL and then behave exactly as if you were working with the site for real: the pages and your actions are visible in special browser window, making website monitoring setup as simple as simple clicking and entering (if necessary) some text into forms fields.

\section{b) Theoretical framework}

The theories relevant to the subject of this study are:

\section{i) Innovation Diffusion Theory (IDT)}

Diffusion of Innovations is a theory propounded by Rogers in 2003. It seeks to explain how, why, and at what rate new ideas and technology spread through cultures. The Innovation Diffusion Theory (IDT) is a model that explains the process by which innovations in technology are adopted by users. Rogers defines innovation as an idea, practice or object that is perceived as new by individual or other unit of adoption. It follows that IDT focuses on explaining how new ideas and concepts gain widespread adoption. 


\section{Macrothink

\section{ii) Technology Acceptance Model (TAM)}

Technology Acceptance Model (TAM) would be the theory that this study is based on. TAM is based on the Theory of Reasoned Action; Davis (1986) developed the Technology Acceptance Model, which deals with the prediction of the acceptability of a tool and to identify the modifications that must be brought to the system in order to make it acceptable to users. This model suggests that the acceptance of an information system is determined by perceived usefulness and perceived ease of use. Perceived usefulness is defined as the degree to which an individual believes that the use of an information system will improve performance. Perceived ease of use refers to the degree to which an individual believes that the use of a system will not require much struggles.

\section{Method and Analysis}

The researcher adopted experimental design for the work. Here the researchers want to evaluate if the value of electronic banking transaction has effect on banks' profit. Data were collected from CBN statistical bulletin 2019 and NDIC annual report 2019. CBN statistical bulletin and NDIC annual report 2019 and NDIC annual report 2019 therefore become the instruments for data collection. The data collected here are very useful, valid and reliable having been audited by both internal and external auditors.

The population consists of the twenty-one (21) deposit money banks registered in Nigeria. Purposive sampling method was adopted to select the sample size of fourteen (14) years (2006-2019). This is because the electronic banking is a new innovation in Nigeria and the data available is scarce, hence, the need to use our best of judgement.

The model specification is given as:

$$
\mathrm{PBT}=\mathrm{f}(\mathrm{ATM}, \text { POS, MB, WIT }+\mathrm{u})
$$

This can be transmodified as:

$$
\begin{aligned}
& \operatorname{LogDPBT} T_{t}=\alpha_{0}+\sum_{i=1}^{n} \beta_{1 i} \operatorname{LogDPBT}_{t}+\beta_{1} \operatorname{LogDPBT} T_{t-1}+\sum_{i=0}^{n} \beta_{2 i} \operatorname{LogDATM}_{t}+ \\
& \operatorname{LogD} \beta_{2} \mathrm{ATM}_{\mathrm{t}-1}+\sum_{\mathrm{i}=1}^{n} \beta_{3 \mathrm{i}} \operatorname{LogDPOS} 2_{\mathrm{t}}+\beta_{3} \operatorname{LogDPOS}_{\mathrm{t}-1}+ \\
& \sum_{i=0}^{n} \beta_{4 i} \operatorname{LogDMB} 3_{t}+\beta_{4} \log D M B_{t-1}+\sum_{i=0}^{n} \beta_{5 i} \log D W I T 4_{t}+ \\
& \beta_{s} \log _{\text {DWIT }}+\mathrm{U}
\end{aligned}
$$

Where PBT $=$ Profit before tax

$\mathrm{ATM}=$ Automated tellers machine

POS $=$ Point of sale

$\mathrm{MB}=$ Mobile Banking

$\mathrm{WIT}=\mathrm{Web}$ internet transaction

$\alpha=$ constant intercept 
$\log =$ Logarithm 2021, Vol. 8, No. 1

" $\beta_{1}, \beta_{2}, \beta_{3}, \beta_{4}, \beta_{5},=$ Coefficient of independent variables"

$\mu=$ error term.

Aprior expectation: A positive significant effect is expected between microfinancing variables such as ATM, POS, MB, WIT and profit before tax (PBT).

The researcher employed stationarity test and autoregressive distributive lag (ADRL) tests for the analysis.

\section{(i) Unit root test}

"Unit root was used to determine the stationarity of the time series data employed. This is to ensure that employment of the data do not lead to spurious estimates. The Augmented Dickey Fuller (ADF) test was employed and while the decision rule is to reject the null hypothesis if the ADF test statistic is absolutely greater than the corresponding Mackinnon's Critical Values at 5\% levels of significance" (p. 12).

\section{(ii) Autoregressive Distributive Lag (ADRL) test}

ARDL created by pesaran and Shin (1999) is adjudged to be superior to Johansen's co-integration because of the following: primarily, it makes use of undersized test range. Two sets of analytical values are offered, shorter and higher values boundaries for all set of descriptive variables into pure I(1), I(0) or both furthermore, Johansen's procedure needs that the variables should be combined of similar order, whereas ARDL doesn't compels the variables to be integrated of the similar order. Thirdly, ARDL method offers an impartial longrun approximation with cogent $t$-statistic if several of the regressors model are endogenous. Lastly, these technique delivers a process of evaluating the short run and long run upshots of one variable on the other and as well single out both once as uitablerange of the arrangement of the ARDL model is made. In this regard, Akaike info criterion (AIC) is chosen.

Also Note that:

i. Coefficient of determination $\mathrm{R}$ was used to describe the goodness of fit of regression.

ii. T-test was used to test for the significance of each of the variables in the model.

iii. F-test was used to test the overall significance of the model

iv. Durbin-Watson was used to test for serial autocorrelation.

On the apriori, the study expects: $b>0, b>0, b>0 \mu=$ error term.

\section{iii Data presentation and analysis}

The data used for the work is presented below: 


\section{Mll Macrothink}

Table 1. Profit Before tax (PBT), Automated Tellers Machine (ATM), Point of Sale (POS), Mobile Banking (MB) Web (internet) Transaction (WIT), in billions 2006-2019

\begin{tabular}{llllll}
\hline YEARS & PBT & ATM & POS & MB & WIT \\
\hline 2006 & 181.04 & 41.3 & 0.06 & 0 & 0.01 \\
2007 & 619.16 & 90.3 & 3.77 & 0 & 1.2 \\
2008 & 658.1 & 211.78 & 6.19 & 0.01 & 5.5 \\
2009 & $-1,373.33$ & 548.6 & 11.03 & 1.27 & 84.15 \\
2010 & 607.34 & 399.71 & 12.72 & 6.65 & 25.05 \\
2011 & -6.71 & $1,561.74$ & 31.02 & 18.98 & 59.61 \\
2012 & 458.04 & $1,984.66$ & 48.01 & 31.51 & 31.57 \\
2013 & 539.97 & $2,828.94$ & 161.02 & 142.8 & 47.32 \\
2014 & 601.02 & $3,679.88$ & 312.07 & 346.47 & 74.04 \\
2015 & 630.1 & $3,970.25$ & 448.51 & 442.35 & 91.58 \\
2016 & 440.33 & $4,988.13$ & 759 & 756.9 & 132.36 \\
2017 & 150.54 & $6,437.59$ & 435.15 & $1,102.00$ & 184.6 \\
2018 & 310.01 & $6,480.09$ & $1,409.81$ & $1,830.70$ & 404.6 \\
2019 & 400.12 & $6,512.60$ & $3,204.76$ & $4,371.55$ & 478.13 \\
\hline
\end{tabular}

Source: CBN statistical Bulletin and NDIC Annual Report and Account 2019.

Aprior expectation: A positive significant effect is expected between the values of transaction variables such as ATM, POS, MB, WIT and profit before tax (PBT).

Table 2. Stationarity (Unit Root) test results

\begin{tabular}{|c|c|c|c|c|c|c|}
\hline \multirow{2}{*}{$\begin{array}{l}\text { (Difference) } \\
\text { Variables }\end{array}$} & \multirow{2}{*}{$\begin{array}{l}\text { ADF Test } \\
\text { Statistic }\end{array}$} & \multicolumn{3}{|c|}{ Mackinnon's Critical Values at $1 \%, 5 \%$ \& $10 \%$} & \multirow{2}{*}{$\begin{array}{l}\text { Order of } \\
\text { Integratio n }\end{array}$} & \multirow{2}{*}{ Prob. } \\
\hline & & $1 \%$ & $5 \%$ & $10 \%$ & & \\
\hline DPBT & -4.443379 & -4.992279 & -3.875302 & -3.388330 & $1(1)$ & 0.0219 \\
\hline DATM & -4.292600 & -5.124875 & -3.933364 & -3.420030 & $1(1)$ & 0.0308 \\
\hline DPOS & -7.987323 & -4.886426 & -3.828975 & -3.362984 & $1(0)$ & 0.0002 \\
\hline DMB & -9.274573 & -5.124875 & -3.933364 & -3.420030 & $1(0)$ & 0.0001 \\
\hline DWIT & -6.197753 & -5.124875 & -3.933364 & -3.420030 & $1(0)$ & 0.0027 \\
\hline
\end{tabular}

Source: Extracts from E-Views 9 Output.

Table 2 presents the unit root stationarity test results for the employed data. The information on the table showed utilized maximum of 2 with trend and intercept after logging the data. Generally, the absolute values of the ADF test statistic for all the employed study variables are higher compared to all their corresponding Mackinnon's critical values at $1 \%, 5 \%$ and $10 \%$ respectively. In all, the study variables are integrated of order $\mathrm{I}(1)$ and $\mathrm{I}(0)$. As such, 


\section{Macrothink}

International Journal of Regional Development

ISSN 2373-9851

2021, Vol. 8, No. 1

they are deemed fit for utilization in subsequent estimations. Since the result are integrated of order I(1) and I(0), it therefore suggests the use of ADRL for the analysis.

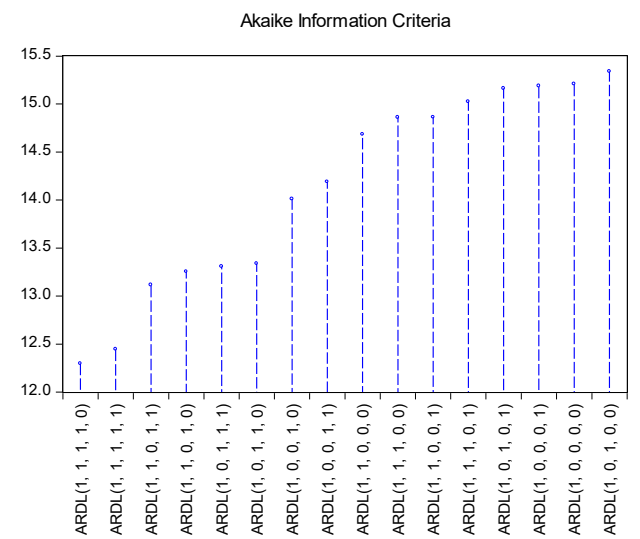

Figure 1. Auto-Regressive Distributed Lag (ADRL) Model selection test result

Source: Eview version 9.

The utilization of this methodology is shielded by the succinct data range. The researchers choose a maximum order of 1 for the provisional ARDL vector error correction model by using the Akaike information criteria (AIC). Number of models evaluated was 16 and the result shows that the best model is ARDL( $\left(\begin{array}{lllll}1 & 1 & 1 & 1 & 0\end{array}\right)$ which was summarized in graph above.

Table 3. Auto-Regressive Distributed Lag (ADRL) shortrun result

\begin{tabular}{lllll}
\hline Variable & Coefficient & Std. Error & t-Statistic & Prob.* $^{*}$ \\
\hline DPBT(-1) & -1.177273 & 0.232166 & -5.070818 & 0.0368 \\
DATM & -0.464204 & 0.155147 & -2.992031 & 0.0959 \\
DATM(-1) & 0.231659 & 0.105686 & 2.191963 & 0.1597 \\
DPOS & 180.2591 & 237.6290 & 0.758574 & 0.5273 \\
DPOS(-1) & 208.2383 & 100.9938 & 2.061892 & 0.1753 \\
DMB & 1124.183 & 393.1707 & 2.859274 & 0.1036 \\
DMB(-1) & -846.6560 & 156.7520 & -5.401244 & 0.0326 \\
DWIT & -951.1042 & 178.2128 & -5.336902 & 0.0334 \\
C & 122.3042 & 432.7322 & 0.282632 & 0.8040 \\
R-squared & 0.984942 & Mean dependent var & -23.45273 \\
Adjusted R-squared & 0.924710 & S.D. dependent var & 426.7934 \\
S.E. of regression & 117.1077 & Akaike info criterion & 12.29568 \\
Sum squared resid & 27428.42 & Schwarz criterion & 12.62123 \\
Log likelihood & -58.62624 & Hannan-Quinn criter. & 12.09047 \\
F-statistic & 16.35255 & Durbin-Watson stat & 2.737837 \\
Prob(F-statistic) & 0.048885 & & \\
*Note: p-values and any subsequent tests do not account for model & \\
selection. & & & \\
\hline
\end{tabular}




\section{Macrothink}

From table 3, ATM, POS, MB and WIT are the independent variables where as the PBT is the dependent variable. The result of the analysis shows that ATM, POS and MB are not significant where as WIT has negative significance at 5 percent level of significance during the period of the study. The coefficient of determination $\left(\mathrm{R}^{2}\right)$ of 0.984942 , which implies that variations in all the explanatory variables account for $98.49 \%$ of the variations in profit before tax, while the rest $1.51 \%$ of the variations is attributable to other variables not captured in the study. F - Statistic measures the overall significance of the model. The F-statistic is 16.35255 and the probability of F-statistic is 0.048885 . This is less than 0.05 power of test. This means that though the individual variables under study have no or negative significance on banks profit but their joint effort has great significance in the banks' profits. Durbin Watson is 2.737837 showing the absence of auto correlation.

The individual variables under study not having significant effect could be as a result of fraud perpetrated in the banking industry through these gargets over the years as reported by CBN Quarterly Report and CBN Financial Stability Report 2019.

Table 4. ARDLBound cointegration test

\begin{tabular}{lll}
\hline Test Statistic & Value & $\mathrm{K}$ \\
\hline F-statistic & 3.384382 & 4 \\
\multicolumn{2}{l}{ Critical Value Bounds } & \\
Significance & I0 Bound & I1 Bound \\
$10 \%$ & 2.45 & 3.52 \\
$5 \%$ & 2.86 & 4.01 \\
$2.5 \%$ & 3.25 & 4.49 \\
$1 \%$ & 3.74 & 5.06 \\
\hline
\end{tabular}

Source: Extracts from E-Views 9 Output.

The bound cointegration test is to check whether there will be longrun relationship.

If the value of F-statistic is higher than the upper bound, then we accept that there will be longrun relationship. From the result, the outcome showed that the F-statistic result 3.384382 is lower than the upper bound which is 4.01 at $5 \%$ level of significant. There is therefore no cointegration and the error of the shortrun cannot be corrected in the longrun.

\section{Results and discussions}

From the analyses, the unit root result showed that the variables are integrated of order I (1) and $\mathrm{I}(0)$. As such, they are deemed fit for utilization in subsequent estimations.

ARDL short run result showed that ATM, POS, MB and WIT showed that ATM, POS and $\mathrm{MB}$ are not significant whereas WIT has negative significance at 5 percent level of significance during the period of the study. This could be attributed to fraud in electronic 


\section{Macrothink}

banking in Nigeria as reported by CBN Quarterly Report and CBN Financial Stability Report 2019.

The bound test result showed that there is no cointegration and the error of the short run cannot be corrected in the long run.

The coefficient of determination $\left(\mathrm{R}^{2}\right)$ of 0.984942 , which implies that variations in all the explanatory variables account for $98.49 \%$ of the variations in profit before tax, while the rest $1.51 \%$ of the variations is attributable to other variables not captured in the study. F Statistic measures the overall significance of the model. The F-statistic is 16.35255 and the probability of F-statistic is 0.048885 . This is less than 0.05 power of test. This means that though the individual variables under study have no or negative significance on banks profit but their joint effort has great significance in the banks' profits. Durbin Watson is 2.737837 showing the absence of auto correlation.

\section{Conclusions and Futures Studies}

From the findings, it is very apparent that the value and the cost of the transactions of ATM, POS and MB have no significant effect on the profit of banks and WIT has negative effect on banks' profit but the combination of all these electronic gadgets yield great impact on the banks.

Therefore, we recommend that banks should fully utilize the benefits provided through electronic banking by ensuring that more ATM terminals are provided in order to reduce crowd, professionals that can constantly put the machine in order should be emlpoyed and there should be constant money in the machine to enable the banks make more profits and serve the general public better.

POS should be made available to the users and at a reduced cost without hidden charges to enable people of different categories have access to them. This will help to generate revenue to the banks and reduce their cost of transaction.

Adequate publicity should be made on mobile banking to sensitize the banking publics on its operational mechanism and on the ease of operation. This will also boost the banking revenue.

Web (internet) transaction should be well publicized and be effectively managed to avoid the negative effect on banks' profit.

The work is also recommended for further studies by the willing researchers using ROA or $\mathrm{ROE}$ as the proxy for performance.

\section{References}

Brooks, C. (2008). Introductory econometrics for finance (2nd ed.). Cambridge, Cambridge University Press.

CBN. (2018). Central bank of Nigeria statistical bulletin various issues, Abuja Nigeria.

Dabwor, T. D, Ezie, O., \&Anyatonwu, P. (2017). Effect of ICT adoption on competitive 


\section{Macrothink}

performance of banks in an emerging economy: The Nigerian experience. Journal of Humanities and Social Science 22(8).

Daniel, E. (1999). Provision of electronic banking in the UK and the Republic of Ireland. International Journal of Bank Marketing, 17(2), 72-83.

Davis, F. D (1989) Perceived usefulness, perceived ease of use, and user acceptance of information technology. MIS Quarterly, Minneapolis (MN), 13(3).

Essinger, J. (1999). The Virtual Banking Revolution: The customer, the bank and the future $\left(1^{\text {st }}\right.$ ed.). International Thomson Business Press, London, UK.

Ihenetu H. I. (2008). Research made easy, Port Harcourt. Hyman consulting and training services.

NDIC. (2018). NDIC annual report and account Abuja Nigeria.

Nigerian National Policy for Information Technology. (2001). National Information Technology Policy. Abuja Nigeria

Ojokuku, R. M., \& Sajuyigbe, A. S. (2012). The Impact of Electronic Banking on Human Resources Performance in the Nigerian Banking Industry. International Journal of Economic Development Research and Investment, 3(2), 61-69.

Pesaran, M. H., \& Shin, Y. (1999). An Autoregressive Distributed Lag Modelling Approach to Cointegration Analysis. In Strom, S. (Ed.), Econometrics and Economic Theory in the 20th Century: The Ragnar Frisch Centennial Symposium. Cambridge University Press.

Rogers, E. M. (2003). Diffusion of innovations (5th ed.). New York: Free Press.

Shehu, U. H., Aliyu, M., \& Musa, A. F. (2013). Electronic banking products and performance of Nigerian listed deposit money banks. American Journal of Computer Technology and Application, 1(10), 138-148.

\section{Copyright Disclaimer}

Copyright for this article is retained by the author(s), with first publication rights granted to the journal.

This is an open-access article distributed under the terms and conditions of the Creative Commons Attribution license (http://creativecommons.org/licenses/by/3.0/). 